\title{
Design of Adobe Bricks of Local Raw Materials for Use in the Monuments of Earthen Architecture (Case of Adrar Hospital) Algeria
}

\author{
M. Hamiane ${ }^{1, *}$, I. Djefour ${ }^{1}$, H. Merabet ${ }^{1}$, D. Bouallala ${ }^{2}$, A. Zekagh ${ }^{3}$, Y. Turki ${ }^{4}$, M. Saidi ${ }^{1}$ \\ ${ }^{1}$ Materials Engineering Department, Research Unit of Materials, Processes and Environment (URMPE), University of Boumerdes, Algeria \\ ${ }^{2}$ BET Tarchid, Algeria \\ ${ }^{3}$ National Office of Management and Protection of Cultural Heritage, Algeria \\ ${ }^{4}$ National Centre for Architecture in Earth, Ministry of Culture, Algeria
}

Copyright $\mathrm{O} 2016$ by authors, all rights reserved. Authors agree that this article remains permanently open access under the terms of the Creative Commons Attribution License 4.0 International License

\begin{abstract}
The earthen architecture has evolved through generations using local materials. The earthen material has proven its validity in time and its efficiency in the architectural solutions and design. Also this material has proven its capacity of protection against the influence of climatic and environmental factors. It meets the needs of the population and it is social, cultural and economic development. Despite the advantages of the strengths and the many features that make earthen the first building material in desert areas, others disadvantages must be taken into account through improve it for more efficient use. The scientific study will improve the earthen material properties so, that, it becomes more resistant to humidity and erosion. Structural restoration of old buildings requires respect of their original architectures and knowledge of the characteristics of the materials used. To this end, our study aims is to develop earthen compositions (Adobe), compatible with original materials building of the monument materials, with better performance, for a proper restoration. The results of physical and mechanical characteristics of the compositions prepared in laboratories showed performance characteristics and compatible with the materials of the Adrar hospital. These final results will allow us for proper restoration of the monument.
\end{abstract}

Keywords Raw Materials, Earthen Architecture, Development Earthen Composition, Adrar Hospital, Adobe, Characteristic, Restoration

\section{Introduction}

The Adrar hospital (fig. 1) was built in 1942, designed by a French architect of Belgian origin, Michel Luycks. It was built in earthen brick (adobe) masonry earthen mortar (Fig. 2) [1]. Its walls are composed of holders of roof vaults of different areas and different heights. Adobes were made at earthen quarries outside the city of Adrar [2]. The building has been abandoned since the early 1980s, this abandon has increased its degradation. The building has a rectangular shape. It is located in a rectangular enclosure also (Fig. 3). It consists of two main U-shaped bodies [1, 2, 3].

The buildings of both sides of the main entrance, served as housing and guardhouses. Abandonment of the building, land squatters, infiltration of rainwater are the main causes of degradation, peeling plaster, stripping coating it is clearly noted that tear of some parts of adobe bricks.

The collapse of some walls and infiltration of rainwater are visible. The dysfunction of gargoyles and defective channels has an important role in the deterioration of the hospital. Some facades, including the main façade and the underpinnings of the walls, show no alteration $[1,2,3]$.

Restoration of Structures of old buildings, requires respect for their original architecture and knowledge of the characteristics of the materials used $[4,5,6]$. To this end, our study aims to develop earthen compositions based on local raw materials compatible with the building materials of the monument, with better performance. To achieve our goal we have determined the mineralogical and chemical compositions (XRD, X-ray fluorescence) raw materials, particle size by analytical method and physical characteristics. We have then designed the adobe compositions. The results of physical and mechanical characteristics of the compositions prepared in laboratories (CETIM, FSI (ceramic), URMPE) showed the efficiency and compatibility comparing with the characteristics of Adrar hospital building materials [7]. These results allow to an adequate restoration of the monument.

\section{Experimentation}

The objective of our work is the development and 
characterization of an adobe earthen formulation compatible with the building materials of the Adrar hospital. So we try to provide some answers mainly an adequate restoration for old buildings of earthen architecture. To arrive at this goal, we've start the first step by characterizing the raw materials and additives used in the formulation of samples, and then the second step deals with the design and characterization of adobes samples. The figure 4 shows the organigram of the main steps performed in our work.

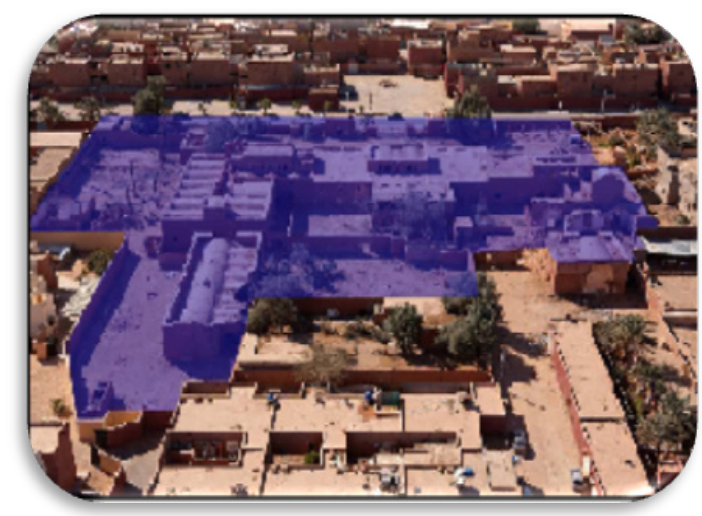

Figure 1. Aerial View of the hospital (Photo: Y. Terki)

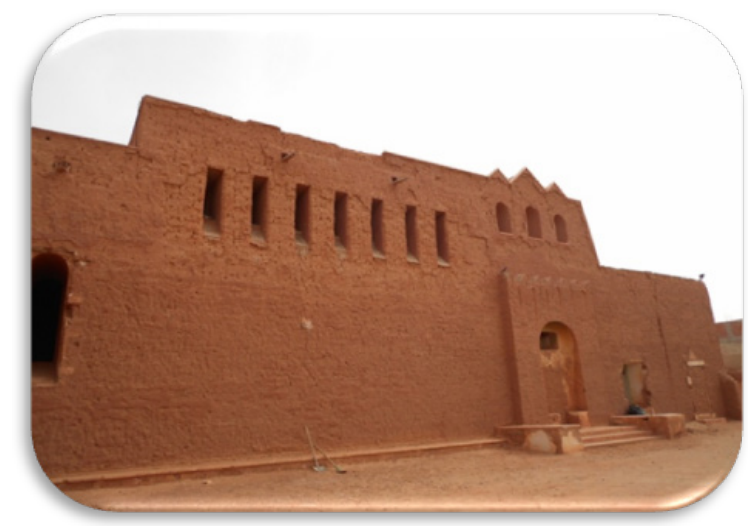

Figure 2. View of main entrance of the hospital (Photo: M. Hamiane)

\subsection{Preparation of the Raw Materials and Additives Used for the Formulation of the Samples}

Raw materials and additives used in the formulation of adobe samples are of local origin. Figure No. 4 shows the Chart of the main steps performed in our work (Raw materials, characterization of samples and method of preparation)

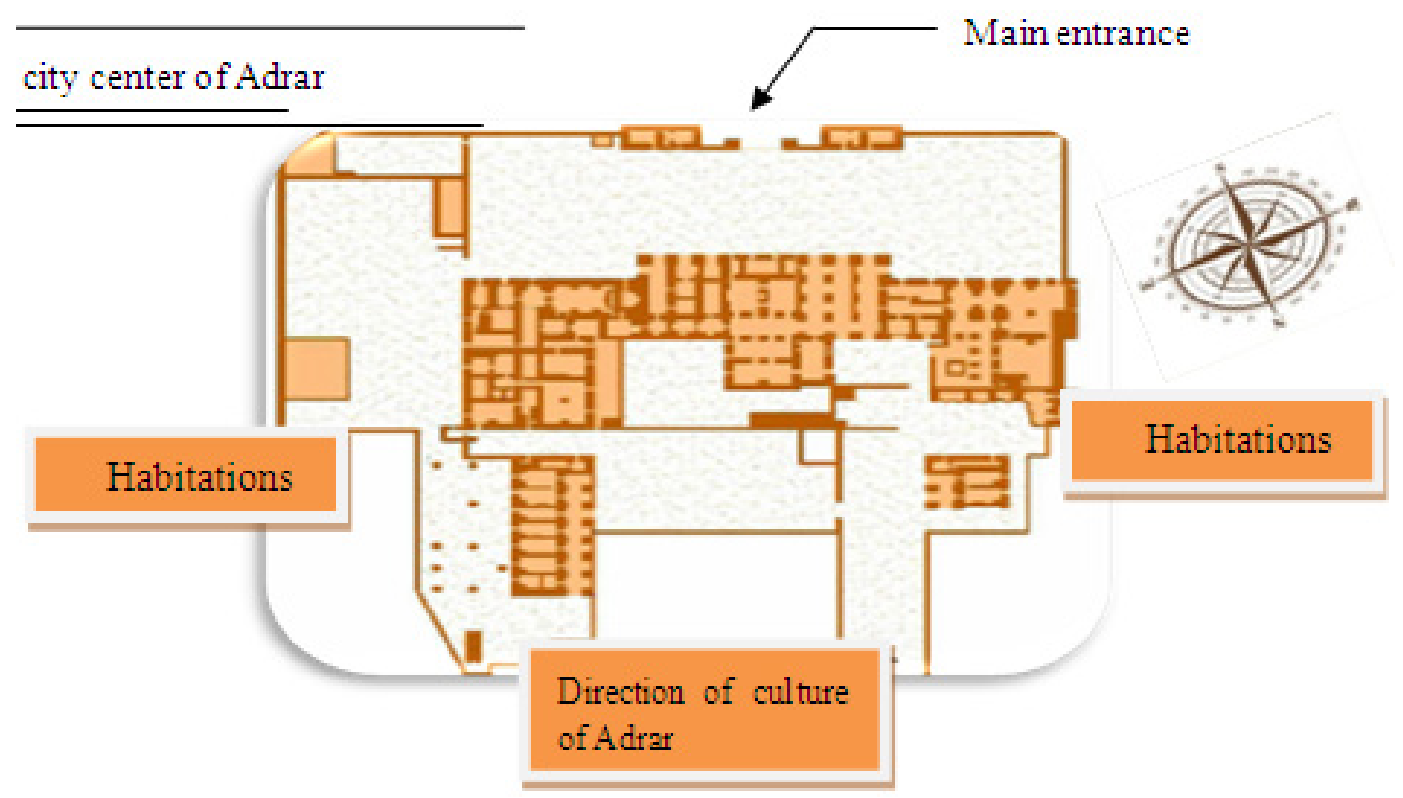

Figure 3. Ground plan of the hospital (Made by BET Adrar) 


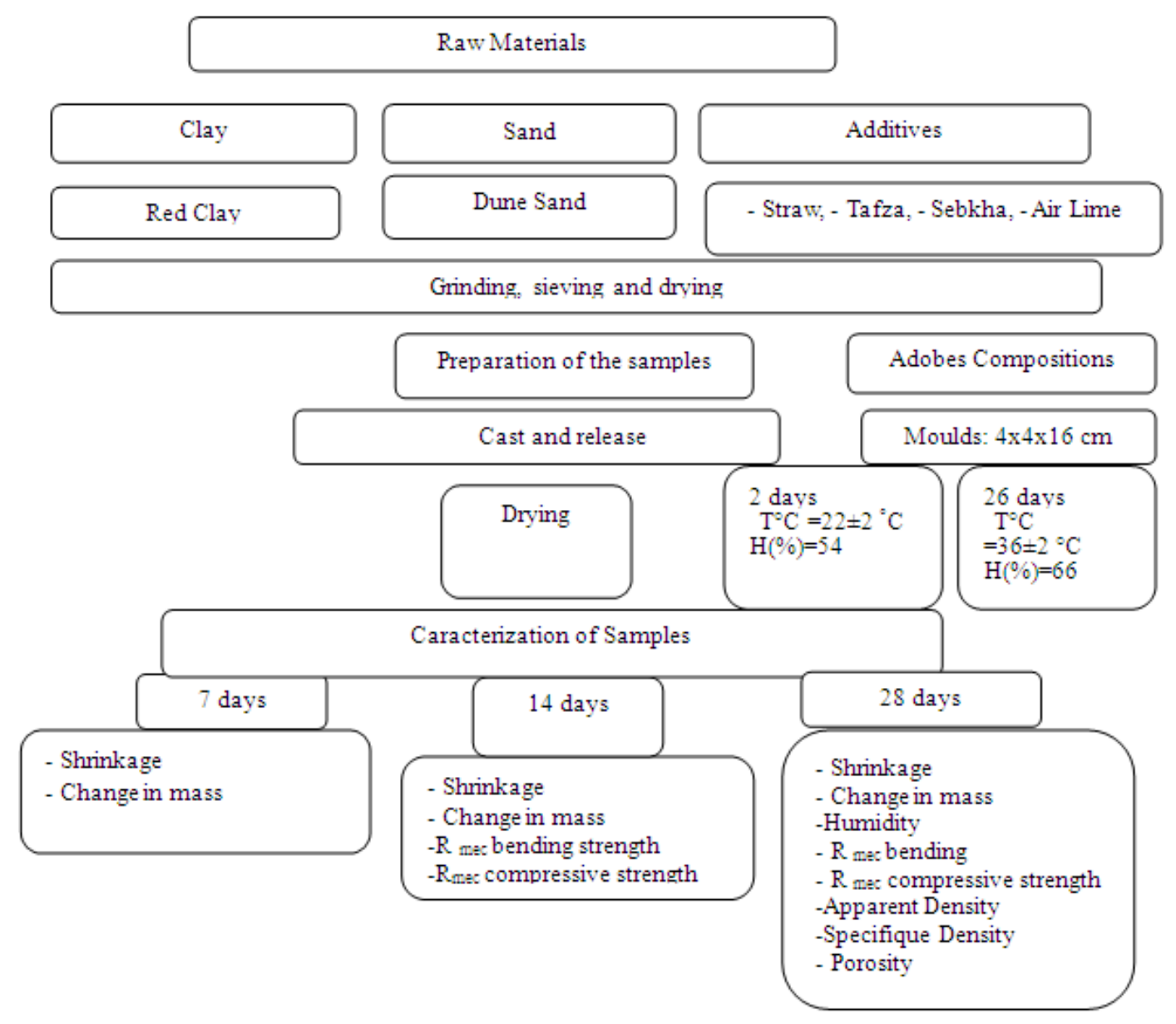

Figure 4. Chart of the main steps performed in our work

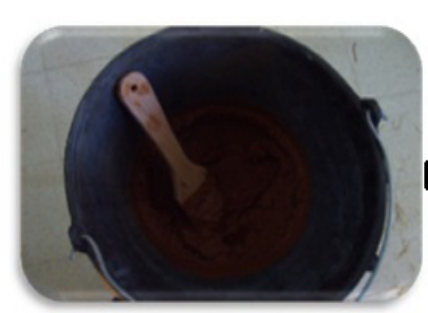

(a)

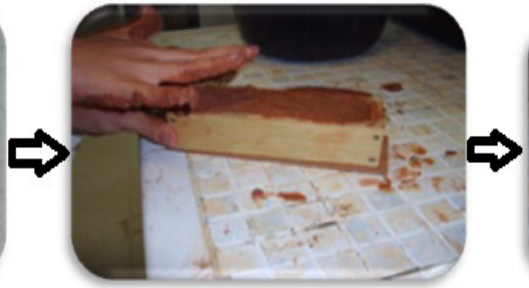

(b)

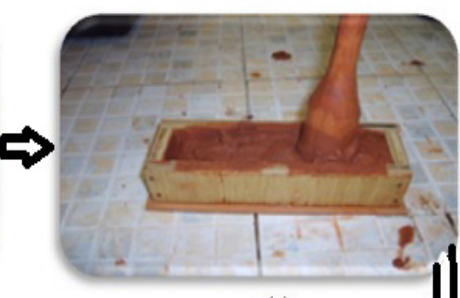

(c)

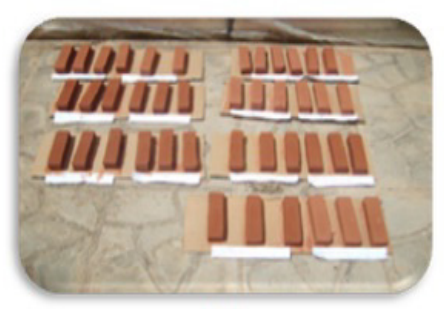

(e)

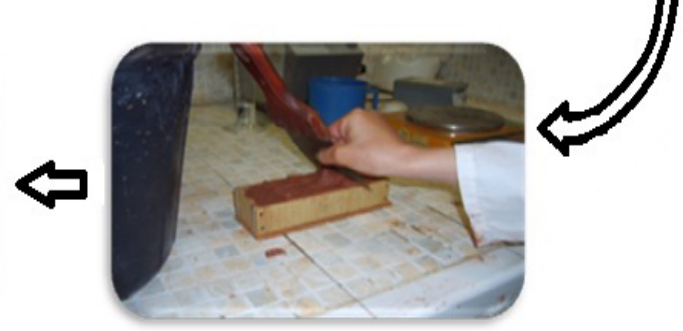

(d)

Figure 5. Shows the steps of samples preparation 


\subsection{Formulation of Adobes Samples}

Several adobe formulations were developed in the laboratory. The choice of developed compositions is based on a literature review; experiences lived by craftsmen and the results of the work in this area. The preparation of the samples is performed in prismatic molds dimension $(4 \times 4 \times 16)$ $\mathrm{cm}$, drying was carried out at room temperature (air), the temperature varies between days $\left(22\right.$ to $38 \pm 2{ }^{\circ} \mathrm{C}$ ).

The formulations are based on control compositions as reference ( $1 \mathrm{~V}$ clay +3.5 to $5 \mathrm{~V}$ sand + water). Additions of between 5 to $20 \%$, of Tafza, straw, sebkha, air lime, and natural cement. The purpose of these additives is to improve the physical characteristics (porosity, shrinkage, humidity ...) and mechanical properties (compressive and bending strength). Drying was carried out at ambient temperature in laboratory rooms, then the air $\left(\mathrm{T}=22 \pm 2^{\circ} \mathrm{C}\right.$, with $\mathrm{H}=$ $50-64 \%)$, then to $\left(\mathrm{T}=36 \pm 2^{\circ} \mathrm{C}\right.$, with $\left.\mathrm{H}=65-68 \%\right)$. This will allow approaching the real and natural in situ production and avoiding cracking. The straw fibers were cut homogeneously (length $3 \mathrm{~cm}$ ) to better assess their effect on the characteristics of the material. The figure 5 shows the steps of samples preparation.

\subsection{Characterization of Raw Materials and Adobes Samples}

Table No. 1 shows the mineralogical compositions and Table 2 physical characteristics of raw materials and additives used in the formulation of the samples.

The adobe samples were characterized (shrinkage, mass change, after 7,14 and 28 days of drying). The mechanical characterization of adobes was made by type of standard NF P-196 at 14 and 28 days ages (after drying). The characterization results of adobe samples are given in table 3

Table 1. Mineralogical compositions of raw materials and additives used in the formulation of the samples

\begin{tabular}{|c|c|c|c|c|c|c|}
\hline \multirow{2}{*}{ Compositions } & \multicolumn{5}{|c|}{ Raw Materials } \\
\cline { 2 - 7 } & Red Clay & Yellow Clay & Green Clay & Sand Dune & Tafza & Sebkha \\
\hline Calcite & + & - & - & + & - & - \\
\hline Hematite & + & - & - & - & - & + \\
\hline Gypsum & - & - & - & + & + & + \\
\hline Orthoclase & - & + & + & + & - & - \\
\hline Albite & - & - & - & + & + \\
\hline Illite & + & + & + & - & + & - \\
\hline Kaolinite & - & - & - & + & + \\
\hline Quartz & + & + & + & - & + & - \\
\hline Dolomite & - & - & - & - & - \\
\hline Gismondine & - & - & - & - & + \\
\hline Tobermorite 9A & - & - & - & - & + \\
\hline $\begin{array}{c}\text { Sodium calcium lead } \\
\text { manganese arsenate (V) }\end{array}$ & - & - & - & - & + \\
\hline
\end{tabular}

Table 2. Physical characteristics of raw materials and additives used for the formulation samples

\begin{tabular}{|c|c|c|c|c|c|}
\hline Samples & $\begin{array}{c}\mathrm{Ms} \\
\left(\mathrm{g} / \mathrm{cm}^{3}\right)\end{array}$ & $\begin{array}{c}\mathrm{Mv} \\
\left(\mathrm{g} / \mathrm{cm}^{3}\right)\end{array}$ & $\begin{array}{c}\mathrm{H} \\
(\%)\end{array}$ & $\begin{array}{c}\mathrm{CaO} \\
(\%)\end{array}$ \\
\hline Green Clay & 2,55 & 1,80 & 3,23 & 8,08 & 0 \\
\hline Yellow Clay & 2,37 & 1,81 & 3,44 & 9,28 & 0 \\
\hline Red Clay & 2,26 & 1,72 & 3,04 & 8,86 & 0 \\
\hline Tafza & 2,13 & 1,78 & 0,41 & 9,34 & 0 \\
\hline Sebkha & 2,19 & 1,18 & 0,62 & 9,35 & 4,48 \\
\hline Sand dune & 2,60 & 1.52 & 0,88 & $/$ & 0 \\
\hline Yellow Sand & 2,02 & 1,53 & 0,40 & $/$ & 0 \\
\hline Black Sand & 2,19 & 1,60 & 0,30 & 1 & 0 \\
\hline Natural Cement & 2,54 & 0,77 & 0,82 & 11,58 & 6,72 \\
\hline Air Lime & 2,54 & 0,81 & 16,03 & 12,87 & 100 \\
\hline Crushed Brick & 1,36 & 1,27 & 1,01 & 10,13 & $/$ \\
\hline
\end{tabular}

Legends: $\mathrm{Mv}=$ Apparent density, $\mathrm{Ms}=$ Specific density, $\mathrm{CaOL}=$ Free Lime; $\mathrm{H}=$ Humidity 


\section{Interpretation of Results}

\subsection{Materials and Additives Used in the Formulation Samples}

The main raw materials used in the formulation are red clay, yellow and green, which act as a binder and give the plastic character to the samples. The dune sand, black sand and yellow sand (figure. 6 show the particle size of different sand), as a degreaser for regulating clays plasticity and participate in the maintenance of mechanical characteristics, the formation of the skeleton samples. Adding: Sabkha, Tafza, air lime, crushed brick and the natural cement aim to improve the physical characteristics (porosity, absorption, hardness) and the mechanical properties of the samples. All raw materials are natural, locally available within the region. Natural cement and crushed brick were imported from North and neighboring regions of Adrar.

Mineralogical analysis shows that the red clay is a material suitable for the manufacture of adobes, especially in desert areas due to normal plasticity, which prevents excessive swelling and cracking. Particle size analysis has allowed us to choose the nature and percentage of sand to add to the composition of adobe.

\subsection{Physical and Mechanical Characteristics of Adobes}

\subsubsection{Witnesses Compositions}

Three witnesses' compositions were selected based on literature references and know-how of Adrar craftsmen .The formula of the main witness composition is:

(1 Volume clay $+3.5 \mathrm{~V}$ to 5 Volume sand + water): The composition ( 1 Volume clay +5 Volume sand + water), give the best physical and mechanical characteristics (Mv: 1.77 $\mathrm{g} / \mathrm{cm}^{3}$; Ms: $2.07 \mathrm{~g} / \mathrm{cm}^{3}$, compressive strength: $1.30 \mathrm{Mpa}$, the shrinkage is $0.40 \%$ and the value of the total porosity is $14.49 \%$. This led us to choose this composition as a reference in our study for the different additives compositions.

\subsubsection{Compositions with Various Additives}

It is noted that increasing of the percentage of straw decreases the density and the specific gravity and increases the compressive strength and flexural strength and stabilizes the shrinkage.

The top three chosen compositions with additives compositions are:

- $\quad$ (1Volume clay +4 Volume sand $+5 \%$ straw + water $)$ with the following characteristics:

Compressive strength of $1.76 \mathrm{MPa}$, the flexural strength of $0.54 \mathrm{MPa}$, a low porosity and shrinkage of $1.42 \%$

- $\quad(1 \mathrm{~V}$ clay $+5 \mathrm{Vsand}+5 \%$ sebkha + water $)$ with the following characteristics: a compressive strength of 1.49 $\mathrm{MPa}$, the flexural strength of $0.54 \mathrm{MPa}$ and a shrinkage of $1.26 \%$

- $\quad(1 \mathrm{~V}$ clay $+5 \mathrm{~V}$ sand $+20 \%$ sebkha + water $)$ with the following characteristics: a compressive strength of $1.46 \mathrm{MPa}$, the flexural strength of $0.56 \mathrm{MPa}$ and a shrinkage of $1.97 \%$

Table 3. Summary of physical and mechanical characteristics of adobes samples bricks

\begin{tabular}{|c|c|c|c|c|c|c|c|c|}
\hline $\mathrm{N}^{\circ}$ & $\begin{array}{c}\text { Samples } \\
\text { adobes }\end{array}$ & $\mathrm{Ms}\left(\mathrm{g} / \mathrm{cm}^{3}\right)$ & $\mathrm{Mv}\left(\mathrm{g} / \mathrm{cm}^{3}\right)$ & $\mathrm{H}(\%)$ & Shrinkage (\%) & Porosity (\%) & $\begin{array}{l}\mathrm{R} \text { comp } \\
(\mathrm{MPa})\end{array}$ & $\begin{array}{l}\mathrm{R} \text { flex } \\
(\mathrm{MPa})\end{array}$ \\
\hline 01 & CTE 1 & 2,24 & 1,86 & 1,47 & 1,42 & 20,43 & 0,85 & 0,59 \\
\hline 02 & CTE 2 & 2,22 & 1,89 & 1,42 & 0,71 & 14,86 & 0,86 & 0,52 \\
\hline 03 & CTE 3 & 2,07 & 1,77 & 1,19 & 0,40 & 14,49 & 1,30 & 0,56 \\
\hline 04 & CPA 1 & 2,67 & 1,83 & 1,40 & 1,42 & 31,46 & 1,25 & 0,51 \\
\hline 05 & CPA 2 & 2,14 & 1,81 & 1,15 & 1,42 & 15.54 & 1,32 & 0,51 \\
\hline 06 & CPA 3 & 1,98 & 1,68 & 1,78 & 1,42 & 15,15 & 1,76 & 0,54 \\
\hline 07 & CSB 1 & 2,26 & 1,87 & 1,36 & 1,26 & 17.25 & 1,49 & 0,54 \\
\hline 08 & CSB 2 & 2,84 & 1,86 & 1,32 & 3,55 & 34,50 & 1,11 & 0,57 \\
\hline 09 & CSB 3 & 2,40 & 1,88 & 1,82 & 4,97 & 21.66 & 1,46 & 0,56 \\
\hline 10 & $\mathrm{CCH} 1$ & 2,36 & 1,81 & 1,13 & 1,97 & 23,30 & 1,04 & 0,55 \\
\hline 11 & $\mathrm{CCH} 2$ & 2,42 & 1,78 & 0,74 & 2,13 & 26,44 & 0,15 & 0,60 \\
\hline 12 & $\mathrm{CCH} 3$ & 2,47 & 1,77 & 0,93 & 2,84 & 28,34 & 0,94 & 0,58 \\
\hline 13 & CTF 1 & 2,14 & 1,82 & 1,16 & 1,42 & 14,95 & 0,63 & 0,65 \\
\hline 14 & CTF 2 & 2,84 & 1,84 & 1,41 & 1,26 & 35,21 & 0,65 & 0,58 \\
\hline 15 & CTF 3 & 2,15 & 1,89 & 1,51 & 4,26 & 12,09 & 0,95 & 0,56 \\
\hline 16 & CAJ 1 & 2,24 & 1,84 & 1,23 & 4,26 & 17,86 & 1,12 & 0,47 \\
\hline 17 & CAJ 2 & 2,40 & 1,83 & 1,39 & 4,68 & 23,75 & 1,24 & 0,44 \\
\hline 18 & CAJ 3 & 2,30 & 1,81 & 1,36 & 4,26 & 22,01 & 21,30 & 0,59 \\
\hline
\end{tabular}

Legends: $\mathrm{Mv}=$ Apparent density, $\mathrm{Ms}=$ Specific density, $\mathrm{CaOL}=$ Free Lime; $\mathrm{H}=$ Humidity, $\mathrm{R}$ comp $=\mathrm{R}_{\text {mec }}$ compression, $\mathrm{R}$ flex $=\mathrm{R}_{\text {mec }}$ bending, 


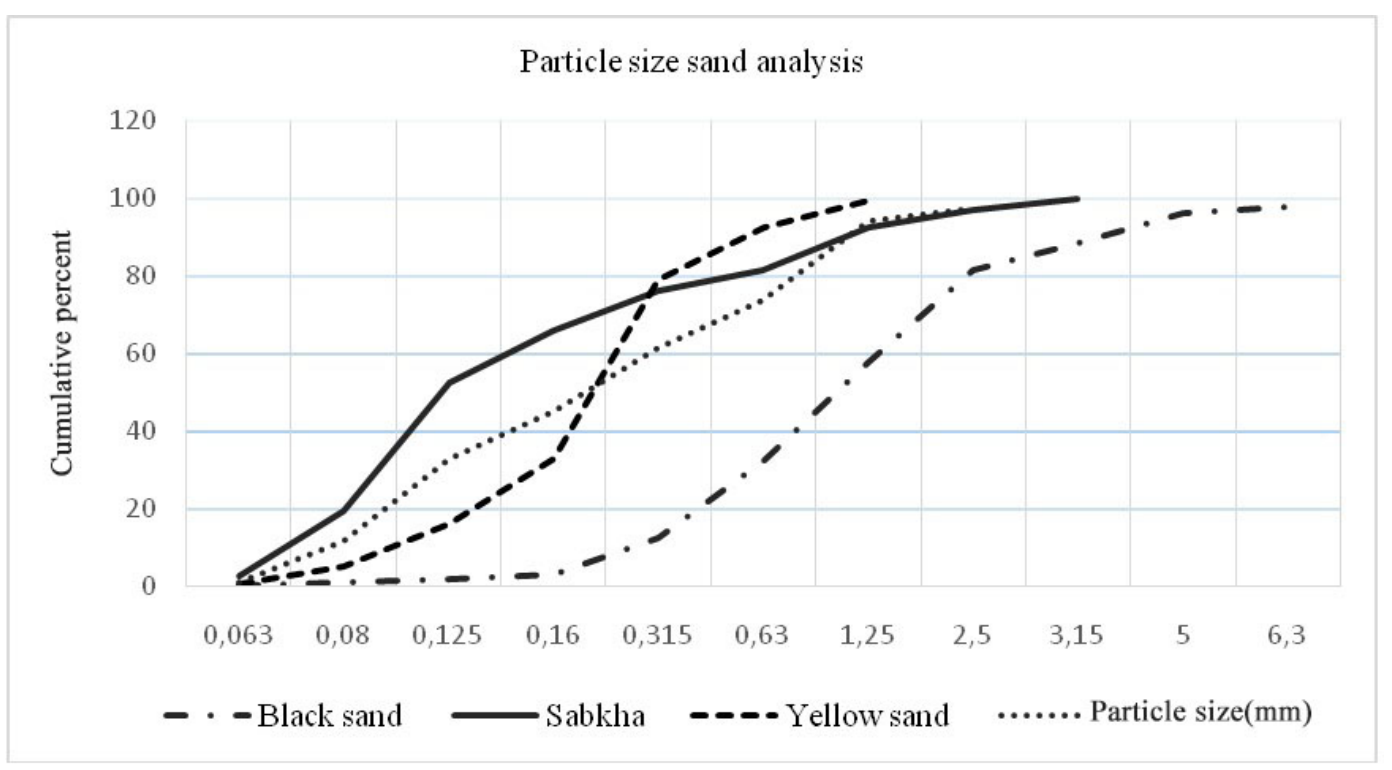

Figure 6. Particle size analysis by sieving (sand)

\section{Conclusions}

- The development of adobes was based on witness's samples which were made by earthen, sand and water, selected references and experienced Adrar craftsmen.

- The witness's composition (1V clay $+5 \mathrm{~V}$ sand + water) give the best physical and mechanical results compared to other compositions. This composition was chosen as a reference for other additives.

- The addition of $5 \%$ of straw and / or $5 \%$ of Sebeka, can improve the physical and mechanical characteristics of adobe bricks. They increase the mechanical strength; the porosity decreases and stabilizes or reduces shrinkage.

- Local raw materials (red clay, green, yellow), sand dune and sebkha are suitable to be used for the development of adobe bricks.

- The addition of straw and sebkha material, or air lime can be added to these raw materials to improve their physical and mechanical properties.

- The red clay taken from quarries Adrar is moderately plastic, is suitable for the production of adobes bricks.

\section{REFERENCES}

[1] Djellou, D., 2011, Report of the Study Office of Adrar. (BET Tarchid) .Algeria.

[2] Imane, D., Hafida, M., Messaoud, H. , 2012, Design and characterization of adobes, mortars and clay plasters for restoration of the Adrar hospital, Boumerdes , Algeria. Magister Thesis, University M'Hamed Bougara Boumerdes, p101-233.

[3] Messaoud, H., 2011, Expertise report of the hospital Adrar conservation. Algeria.

[4] Anil, A,. 1981, Building in earthen: the potential of materials based on earthen for third World habitat (ed.), Earthscan , London, p23 -41.g

[5] Bruno, P., 2005, Earthen materials, Technical building and restoration (ed.), Eyrolles, France, pp. 62-75.

[6] Hugo, H., Hubert. G., 2006 Treaty of earthen architecture building, (ed.), Incidentally, CRAterre, France, P260 -289.

[7] Messaoud, H, Imane, D., Hafida, M., 2014, Design of adobes bricks from local raw materials for use in the monuments of earthen architecture (case of Adrar hospital), Algeria. Proceeding of the international conference on conservation of stone and earthen architectural heritage, p221 -227. 